\title{
Mencari Bentuk Pembelajaran Rancang Kota dalam Konteks Adaptasi Kebiasaan Baru
}

\author{
Dyah Titisari Widyastuti \\ Departemen Teknik Arsitektur dan Perencanaan, Fakultas Teknik, Universitas Gadjah Mada \\ Jl. Grafika No. 2 Kampus UGM, Yogyakarta \\ Email: dyahtitisariw@ugm.ac.id
}

\begin{abstract}
Abstrak
Dalam kondisi pandemi, di mana proses belajar mengajar di berbagai tingkat pendidikan menuntut perubahan besar dari yang semula berlangsung secara face-to-face di ruang-ruang kelas institusi pendidikan berubah menjadi screen-to-screen di ruang-ruang personal, sangat penting untuk dibangun alternatif metode pembelajaran yang tepat. Hal ini semestinya tidak sesederhana hanya memindahkan materi di kelas ke dalam layar komputer, namun lebih dari itu adalah bagaimana aspek pedagogi masing-masing keilmuan tetap harus menjadi pegangan, bagaimana capaian pembelajaran bisa dipenuhi setara dengan pembelajaran dalam kondisi normal. Pembelajaran 'desain' pada dasarnya tidak bisa lepas dari pembelajaran proses merancang dalam suatu ruang studio, di mana secara pedagogi mengintegrasikan learner-centered approach, metode interaksi antar pelaku pembelajaran, serta studio sebagai suatu ruang fisik dan sosial yang membentuk atmosfer pemicu kreativitas. Demikian juga pada pembelajaran rancang kota yang mendasarkan pada tidak hanya komponen teoretik namun juga komponen empirik. Kajian ini bertujuan untuk membangun konten dan metode pembelajaran rancang kota, yang tidak lepas dari aspek pedagoginya, sebagai bentuk adaptasi dari norma-norma pembelajaran rancang kota selama masa pandemi dan potensinya sebagai metode pembelajaran alternatif di masa depan.
\end{abstract}

Kata kunci: pembelajaran alternatif, pedagogi, rancang kota.

\section{Abstract \\ Title: Seeking Appropriate Approach for Urban Design Learning under the New Normal Condition}

Basically, it is urgently needed to build appropriate learning methods in the current pandemic condition, where the teaching and learning process at various levels of education demands a major change from what originally took place face-to-face in educational institution classrooms to turning into screen-to-screen in the personal spaces of individual respective environments. This should not be as simple as simply transferring class material onto a computer screen, but more than that, how the pedagogical aspects of each discipline must be fulfilled, how learning competencies can be fulfilled equivalent to learning under normal conditions. Design learning basically cannot be separated from learning the process of designing in a studio, where pedagogically integrates a learner-centered approach, methods of interaction between learners, and the studio as a physical and social space that forms an atmosphere that triggers creativity. Likewise in urban design learning is based on not only a theoretical component but also an empirical component. This study aims to develop content and learning methods for urban design, that cannot be separated from its pedagogical aspects, as a form of adaptation of urban design learning norms during the pandemic period and their potential as an alternative learning method in the future.

Keywords: alternative learning, pedagogy, urban design. 


\section{Pendahuluan}

Kondisi pandemi saat ini menuntut adanya perubahan dan penyesuaian darurat proses pembelajaran pada semua jenjang pendidikan. Perubahan yang 'mendadak' dari pembelajaran tatap muka di kelas menjadi pembelajaran jarak jauh melalui ruang belajar di dunia maya harus disikapi dengan pembaharuan strategi pembelajaran, khususnya dalam konten dan metode pembelajaran. Hal ini tentunya tidak sesederhana memindahkan materi pembelajaran dari face-to-face menjadi screen-to-screen, namun fokusnya lebih pada bagaimana aspek pedagogi masingmasing keilmuan tetap harus menjadi pegangan, dan bagaimana capaian pembelajaran bisa dipenuhi setara dengan pembelajaran dalam kondisi normal.

Pembelajaran rancang kota merupakan bagian dari pembelajaran desain, yang pada dasarnya tidak bisa lepas dari pembelajaran proses merancang dalam suatu ruang studio, di mana secara pedagogi mengintegrasikan learner-centered approach, metode interaksi antar pelaku pembelajaran, serta studio sebagai suatu ruang fisik dan sosial yang membentuk atmosfer pemicu kreativitas. Secara spesifik, pembelajaran rancang kota juga mendasarkan pada tidak hanya komponen teoretik namun juga komponen empirik. Kajian ini bertujuan untuk membangun konten dan metoda pembelajaran rancang kota, sebagai bentuk adaptasi dari norma-norma pembelajaran rancang kota selama masa pandemi dan potensinya sebagai metoda pembelajaran alternatif di masa depan.

\section{Metode}

Dalam upaya mencari bentuk pembelajaran rancang kota yang adaptif pada kondisi adaptasi kebiasaan baru di tengah masa pandemi, dilakukan langkah-langkah sebagai berikut:

(1) Mendalami pustaka terkait pemahaman keilmuan rancang kota (untuk mendalami kembali konten rancang kota), serta aspek pedagogi dalam desain dan rancang kota (untuk mendalami kembali kesesuaian metode dalam pembelajaran rancang kota);

(2) Melakukan kajian kasus pembelajaran matakuliah rancang kota dan evaluasi hasil pembelajarannya pada saat sebelum dan dalam masa pandemi dalam kaitannya untuk menganalisis capaian pembelajaran;

(3) Membangun konten dan metode pembelajaran alternatif untuk rancang kota berdasarkan aspek-aspek pendidikan rancang kota.

\section{Kajian Pustaka}

\section{Memahami Keilmuan Rancang Kota}

Menurut pandangan Vernez-Moudon (1992) dan Madanipour (1996) dalam Banerjee dan Loukaitou-Sideris (2011) serta Lynch (1981), kota memiliki kompleksitas tinggi, oleh karena itu tidak memungkinkan untuk dirancang oleh individu, diperlukan suatu pendekatan multidisipin dan interdisiplin dalam aktivitas dan proses memberikan bentuk (merancang), mengatur serta mengelola lingkungan binaan (built environment). Rancang kota terkait dengan obyek (fisik), aktivitas 
manusia, institusi yang mengelola dan dengan proses perubahan. Secara lebih spesifik, Abrams (1971) mendefinisikan rancang kota sebagai suatu disiplin ilmu yang terkait dengan proses memberi bentuk pada sekelompok struktur/elemen perkotaan, pada keseluruhan permukiman, atau pada bentuk kota secara luas. Sementara itu, Rossi (1984) menekankan pentingnya konteks dan respek terhadap konteks pada rancang kota dalam upaya mewujudkan (configurating and constructing) lingkungan yang berkelanjutan, terpadu dan menyatu dengan lanskap kota.

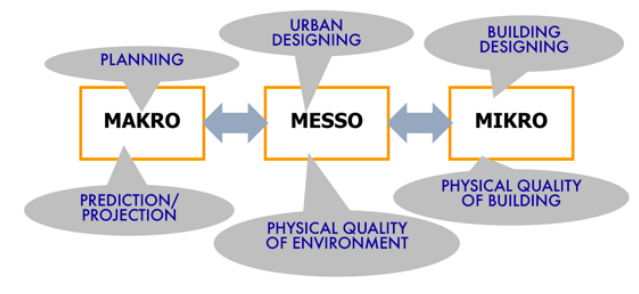

Gambar 1. Kedudukan keilmuan rancang kota

Sumber: Hasil analisis, 2020

Keilmuan rancang kota secara ontologi memiliki obyek material berupa tata ruang yang secara spesifik lingkupnya berada pada skala messo dalam memberikan solusi masalah perkotaan melalui perancangan tiga dimensional. Ditinjau dari aspek aksiologi, fokusnya adalah mengaplikasikan objek material rancang kota secara keilmuan dan praksis untuk meningkatkan kualitas fisik ruang-ruang perkotaan dalam memberikan manfaat untuk kepentingan publik. Dalam kajian epistemologi, rancang kota yang merupakan pumpunan dari keilmuan arsitektur, perencanaan kota dan perancangan lanskap memiliki keterkaitan dengan bidang keilmuan lain yang terkait dengan permasalahan perkotaan, di antaranya ilmu sosial, politik, budaya, ekonomi, hukum, geografi, transportasi, dan sebagainya (Tim Penyusun Proposal Magister Rancang Kota UGM, 2019).

\section{Memahami Pendidikan Rancang Kota}

Pendidikan rancang kota, menurut Lynch (1981) dalam Palazzo (2011) dalam Banerjee dan Loukaitou-Sideris (2011), mencakup tiga pembelajaran kemampuan dasar, yaitu (1) menemukenali interaksi antara manusia, ruang dan tempat, aktivitas dan intitusi yang mengelolanya; (2) memahami teori, teknik/metode, dan nilai-nilai rancang kota; (3) mengkomunikasikan proses dan produk rancang kota dalam bahasa tertulis, bahasa lisan, perhitungan matematis, dan grafis. Dalam hal substansi pembelajaran rancang kota, Lukovich (2017) menekankan bahwa struktur pendidikan rancang kota meliputi pemahaman teoretik (theoretical understanding) dan pengetahuan empirik (empirical knowledge) melalui kelas perkuliahan, kajian kasus dan referensi, kerja studio kolaboratif, kajian lapangan, atau magang kerja profesional. Studio sebagai bagian pendidikan desain yang tidak bisa digantikan, membelajarkan pengalaman learning-by-doing dalam mewujudkan solusi desain (studio culture), termasuk di dalamnya pembelajaran dalam presentasi, kritik dan penilaian. Struktur pembelajaran rancang kota harus meliputi komponen teoretik dan empirik agar dapat memberikan respon kreatif dalam 'designing a system'. Observasi lapangan diperlukan tidak sekedar untuk mendapatkan pemahaman terhadap lingkungan fisik namun juga pemahaman terhadap aktivitas yang 
berlangsung sebagai bentuk interaksi dengan lingkungan fisiknya (Lukovich, 2017 dalam Keswani, 2019).

Pada dasarnya, pendidikan rancang kota mempersiapkan profesional yang mampu memberikan solusi rancang kota tidak sekedar sebagai bentuk beautification ruangruang publik namun lebih pada aktivitas yang membentuk kembali ruang-ruang publik sebagai bagian dari transformasi kota yang mampu mengakomodasi perubahan kondisi kota, produksi dan reproduksi ruang-ruang kota sebagai ruang sosial. Pendidikan rancang kota harus memberikan keseimbangan antara kemampuan teknis dan kreatif, dalam hal ini mencakup pemahaman tempat, kebutuhan sosial, peran aktivitas komunitas, komunikasi dengan penentu kebijakan serta kreativitas mengekspresikan gagasan desain. Untuk mewujudkannya, proses dan metode pembelajaran harus diperkuat dalam pendekatan berbagai isu, tempat dan budaya (Madanipour, 2006 dan Cuthbert, 2007 dalam Palazzo, 2011 dalam Banerjee dan Loukaitou-Sideris, 2011).

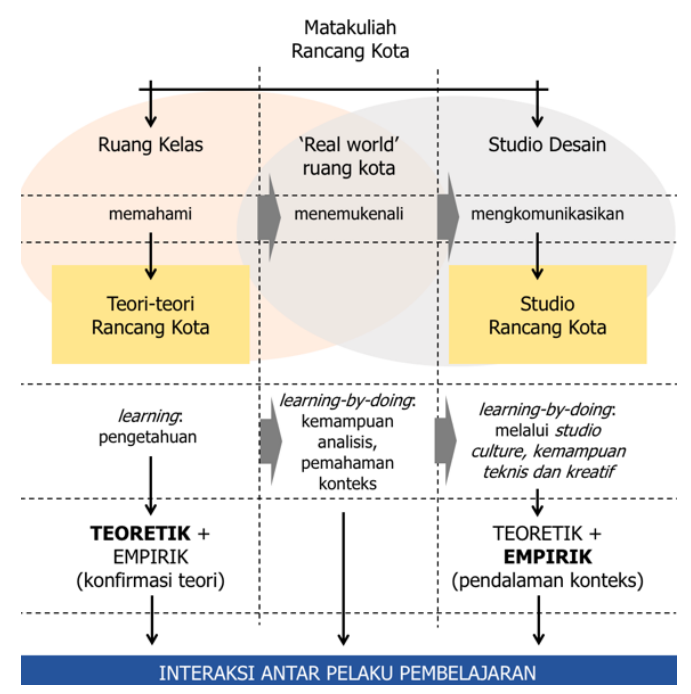

Gambar 2. Esensi pembelajaran rancang kota Sumber: Hasil analisis, 2020

Dari kajian beberapa pendapat terkait pendidikan rancang kota, didapatkan gambaran bahwa pendidikan rancang kota harus mengakomodasi penguasaan teoretik dan empirik, penting adanya pendalaman konteks lapangan dengan berbagai isu dan budaya, yang dapat menumbuhkan solusi teknis dan kreatif dalam rancang kota.

Dalam kurikulum pendidikan rancang kota, selalu meliputi matakuliah-matakuliah teori rancang kota dan matakuliah-matakuliah pendukung, serta matakuliah studio rancang kota. Baik matakuliah teori rancang kota ataupun matakuliah studio rancang kota selalu memiliki muatan teoretik dan empirik dalam konten pembelajarannya. Proporsi teoretik dalam matakuliah teori lebih besar, empirik lebih berperan sebagai sarana konfirmasi teori pada konteks lapangan, untuk mengidentifikasi, dan memahami perwujudan teori secara nyata, yang sangat dipengaruhi oleh isu, budaya, dan konteks fisik lapangan. Sementara itu dalam matakuliah studio rancang kota, proporsi empirik lebih besar dalam arah untuk 
pendalaman konteks lapangan. Teoretik dalam matakuliah studio rancang kota berperan sebagai alat dan dasar pengetahuan untuk memahami konteks lapangan. Berdasarkan kajian esensi pembelajaran rancang kota, dapat disimpulkan bahwa proses pembelajaran rancang kota berlangsung pada 3 (tiga) wadah, yaitu ruang kelas, ruang studio desain dan ruang kota sebagai laboratorium 'real world'.

Sejalan dengan tiga pembelajaran kemampuan dasar dalam pendidikan rancang kota yang disampaikan Lynch (1981) dalam kajian sebelumnya, proses memahami teori, teknik/metode, dan nilai-nilai rancang kota berlangsung dalam ruang kelas, dengan dominasi aktivitas 'learning'. Sementara itu proses menemukenali interaksi antara manusia, ruang dan tempat, aktivitas dan intitusi yang mengelolanya berlangsung pada ruang kota sebagai laboratorium 'real world'. Proses pembelajaran berlangsung dalam bentuk 'learning-by-doing' yang akan mengasah kemampuan analisis untuk pemahaman konteks lapangan. Kemampuan dasar ketiga yang merupakan esensi dari pembelajaran rancang kota berlangsung melalui pembelajaran mengkomunikasikan proses dan produk rancang kota dalam bahasa tertulis, bahasa lisan, perhitungan matematis, dan grafis. Proses ini lebih banyak berlangsung dalam ruang studio desain melalui 'learning-by-doing' dalam studio culture untuk mengasah kemampuan teknis dan kreatif. Keseluruhan proses pembelajaran rancang kota yang berlangsung pada ruang kelas, ruang kota dan ruang studio tersebut memerlukan strategi interaksi dan komunikasi antar pelaku pembelajaran yang tepat untuk dapat mencapai target capaian pembelajaran.

Di sisi lain, proses pembelajaran perancangan atau desain selalu tidak lepas dari kerja studio. Menurut Shuffer (2003) dalam Yorgancioğlu (2020), terdapat tiga komponen utama pedagogi dalam studio desain, yaitu (1) ruang dan fasilitas (surface structure); (2) bentuk pedagogi (pedagogical forms); dan (3) prinsipprinsip epistemologi (epistemological principles). Ruang dan fasilitas dalam hal ini adalah komponen-komponen fisik yang membentuk budaya dan lingkungan studio (waktu, ruang fisik, akses ekspert/mentor, dan media untuk merancang). Bentuk pedagogi adalah lingkup instruksional studio yang terbentuk dari metode belajar mengajar spesifik pendidikan desain yang dilakukan oleh mahasiswa dan mentor (dalam hal ini adalah dosen). Prinsip-prinsip epistemologi terbentuk melalui hidden curriculum, terkait bagaimana penilaian terhadap komponen-komponen selain produk desain (tahap kemajuan yang dicapai, perilaku, disiplin, dan sebagainya).

Sejalan dengan hal tersebut, Haar (2020) dalam Yorgancioğlu (2020) menyatakan bahwa pedagogi studio desain dibentuk oleh (1) pendekatan pembelajaran yang berorientasi pada siswa (student-centered learning); (2) metode komunikasi/interaksi antar pelaku pembelajaran dan pengalaman dalam pembelajaran; serta (3) studio desain sebagai ruang fisik dan sosial di mana pengalaman dalam pembelajaran dan interaksi antar pelaku pembelajaran berlangsung.

Lebih lanjut, Gray (2013) dalam Yorgancıoğlu (2020) menyampaikan terminologi 'habitus of the studio' menjadi hal yang penting dalam pedagogi studio, yaitu budaya studio (studio culture) yang merupakan referensi implisit mengenai pembelajaran yang didapatkan dari interaksi mahasiswa dan mentor, di antaranya cara mahasiswa belajar bagaimana berpikir dan bersikap sebagai perancang, 
bagaimana menggunakan wacana yang berorientasi praktik dan bagaimana mengkritisi produk desain mahasiswa yang lain menggunakan wacana tersebut. Studio tidak hanya sekedar tempat untuk meningkatkan ketrampilan dan pengetahuan namun juga tempat di mana perilaku dibangun. Budaya studio desain ditumbuhkan dan dipraktikkan dalam lingkungan fisik studio dan secara berkelanjutan membelajarkan praktik profesional pada komunitas akademik.

Dengan demikian, jika dikonkretkan lebih lanjut terkait komponen utama pedagogi dalam studio desain sebagai integrated learning space, dapat disimpulkan bahwa aspek surface structure dalam studio rancang kota adalah ruang kerja studio fisik dan sosial serta ruang kota secara nyata, aspek pedagogical forms merupakan metode interaksi antar pelaku pembelajaran dalam studio, sedangkan aspek epistemological principles meliputi substansi teoretik dan empirik dalam pembelajaran studio serta studio culture yang lebih bersifat student-centered learning.

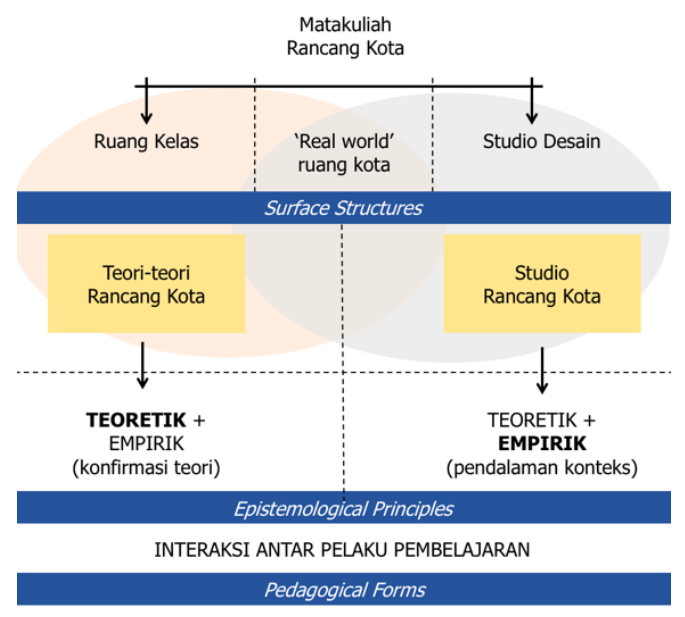

Gambar 3. Komponen pendidikan rancang kota dengan studio sebagai integrated learning space

Sumber: Hasil analisis, 2020

\section{Hasil dan Pembahasan}

\section{Mengevaluasi Bentuk Pembelajaran Rancang Kota: Capaian Pembelajaran Matakuliah}

Capaian pembelajaran lulusan (CPL) dapat menjadi tolok ukur sejauh mana proses pembelajaran sudah dilakukan dengan baik. Pada saat terjadi perubahan sistem pembelajaran seperti dalam era adaptasi kebiasaan baru, CPL seharusnya tetap dapat terpenuhi.

Sebagai kasus kajian, digunakan pembelajaran rancang kota yang berlangsung di lingkungan Departemen Teknik Arsitektur dan Perencanaan Fakultas Teknik Universitas Gadjah Mada, pada salah satu matakuliah studio, yaitu Studio Pendalaman Konteks Desain Kawasan Binaan (pada jenjang magister). Matakuliah ini sudah berlangsung pada semester genap tahun akademik 2019/2020 yang lalu. Dalam proses pembelajarannya, matakuliah ini mengalami penyesuaian dalam 
proses pembelajarannya, sebagian dengan proses pembelajaran luring pada kondisi normal dan sebagian sisa waktunya berlangsung dalam proses pembelajaran daring, menyesuaikan tuntutan penyelenggaraan pembelajaran pada masa pandemi.

Capaian pembelajaran mata kuliah untuk Studio Pendalaman Konteks Desain Kawasan Binaan terdiri dari (1) Mampu mengaplikasikan teori, prinsip, dan standar/kaidah rancang kota secara normatif dan inovatif; (2) Mampu menjawab permasalahan kawasan melalui ide, konsep, dan produk yang kreatif berdasar kajian saintifik; (3) Mampu menyajikan solusi disain kawasan melalui serangkaian strategi yang dikerjakan secara berkelompok maupun individu.

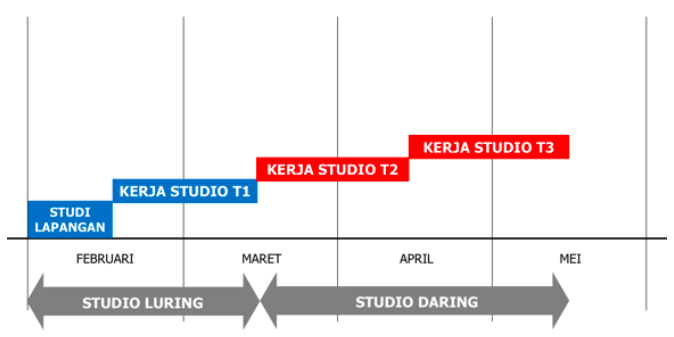

\section{Gambar 4. Penyesuaian Tatakala Pelaksanaan Pembelajaran Matakuliah Studio Pendalaman Konteks Desain Kawasan Binaan Semester Genap 2019/2020 \\ Sumber: Hasil analisis, 2020}

Jika dikaitkan dengan tiga pembelajaran kemampuan dasar rancang kota yang disampaikan Lynch (1981) pada kajian sebelumnya, capaian pembelajaran pertama merupakan representasi dari kemampuan memahami, capaian pembelajaran yang kedua merupakan representasi dari kemampuan menemukenali, sedangkan capaian pembelajaran yang ketiga merepresentasikan kemampuan mengkomunikasikan.

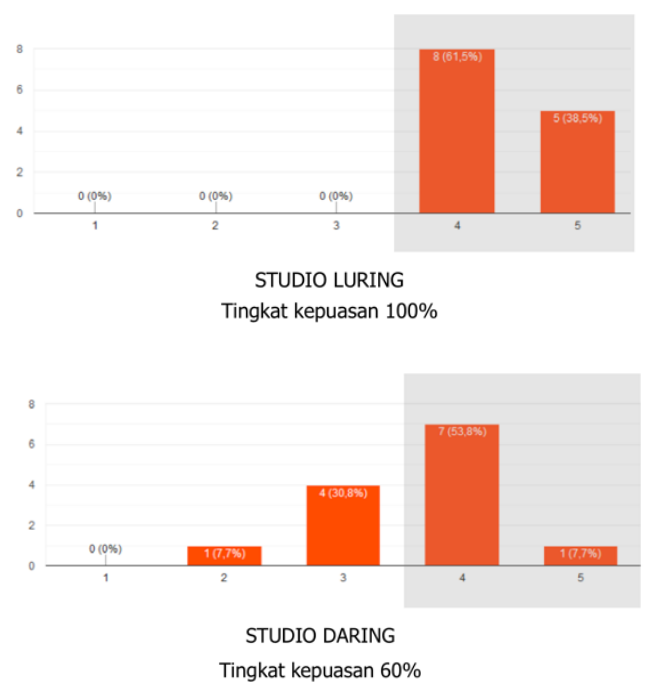

Gambar 5. Evaluasi tingkat kepuasan mahasiswa

Sumber: Data evaluasi dosen oleh mahasiswa, Program Magister Teknik Arsitektur UGM, 2020

Dalam hasil evaluasi matakuliah, didapatkan gambaran tingkat kepuasan mahasiswa terhadap proses pembelajaran yaitu pada waktu proses pembelajaran 
dilakukan secara luring, dalam hal ini proses pendalaman teori dan konteks masih dilakukan di dalam ruang kelas dan di lapangan, tingkat kepuasan mencapai $100 \%$. Sementara itu pada saat proses pembelajaran dilakukan secara daring, tingkat kepuasan turun menjadi 60\%. Turunnya tingkat kepuasan terhadap proses pembelajaran diidentifikasi sebagai dampak dari ketidaksesuaian metode interaksi dan komunikasi antar pelaku pembelajaran yang belum bisa merespon dengan tepat perubahan proses pembelajaran yang berlangsung pada saat pengerjaan tugas studio. Studio culture yang 'hilang' juga menjadi indikator penyebab tingkat kepuasan terhadap proses pembelajaran daring menurun.

Demikian juga pada capaian pembelajaran kedua, mahasiswa mampu menjawab permasalahan kawasan melalui ide, konsep, dan produk yang kreatif berdasar kajian saintifik dapat dicapai ketika capaian pembelajaran pertama sudah dipenuhi. Dalam pedagoginya, untuk mampu menjawab permasalahan kawasan, harus memahami karakter kawasan terlebih dahulu. Karakter kawasan dipahami melalui observasi lapangan secara komprehensif, baru kemudian mampu mengidentifikasi permasalahan yang eksis dengan menggunakan kemampuan yang didapatkan dari capaian pembelajaran yang pertama. Solusi permasalahan yang diwujudkan melalui ide, konsep, dan produk yang kreatif pada dasarnya dibangun dari atmosfer kerja studio di mana interaksi antar mahasiswa, dan juga interaksi dengan mentor studio akan dapat memunculkan ide-ide desain yang kreatif yang berdasar pemahaman saintifik. Dalam tahap observasi lapangan, proses pembelajaran pada kasus matakuliah ini masih berlangsung secara luring, sehingga tidak ada kendala dalam penguasaan capaian pembelajaran.

Dalam capaian pembelajaran ketiga, pada awalnya mahasiswa mampu menyajikan solusi disain kawasan melalui serangkaian strategi yang dikerjakan secara berkelompok maupun individu pada tugas pertama. Pada saat memasuki tugas ke2 dan ke-3, permasalahan mulai muncul sejalan dengan pelaksanaan pembelajaran secara daring. Ketidaksiapan pelaku pembelajaran dan ketidaksesuaian metode yang dilakukan menyebabkan studio culture yang biasanya berlangsung di ruang kerja studio menjadi hilang atau kurang terakomodasi. Komunikasi dan interaksi tanpa tatap muka dan dengan porsi verbal dan tekstual lebih besar menjadi permasalahan yang harus diperbaiki dalam pembelajaran era adaptasi kebiasaan baru. Hal ini diperkuat dengan beberapa pendapat responden mahasiswa sebagai berikut

(1) Pembelajaran tatap muka lebih efektif, iklim kompetisi lebih terasa untuk menstimulasi ide-ide kreatif;

(2) Observasi lapangan sangat penting untuk kompilasi data dalam upaya pemahaman karakter kawasan, pada pembelajaran jarak jauh akan muncul kesulitan menyamakan persepsi dalam mengkritisi data lapangan;

(3) Komunikasi dengan mentor dan interaksi sosial menjadi terbatas pada pembelajaran jarak jauh.

Namun demikian, jika dilihat dari hasil evaluasi, beberapa poin positif masih bisa didapatkan dari proses pembelajaran dengan blended luring dan daring, dengan pendalaman konteks lapangan secara langsung pada bagian awal pelaksanaan 
studio, di antaranya kemampuan berpikir analitis-kritis, kemampuan interaksi, komunikasi dan presentasi gagasan, serta kemampuan bekerja kelompok.

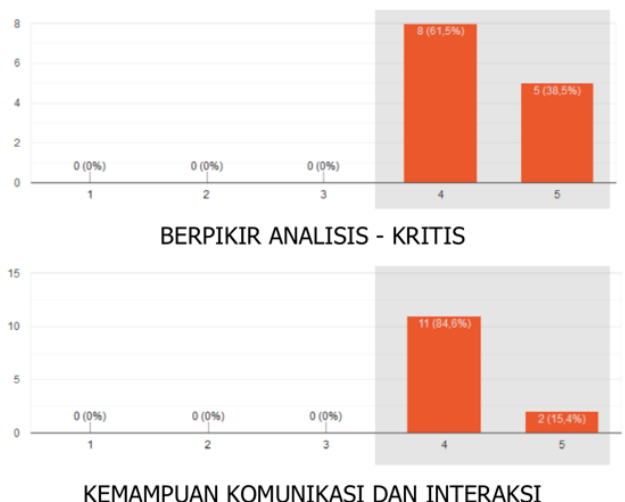

KEMAMPUAN KOMUNIKASI DAN INTERAKSI

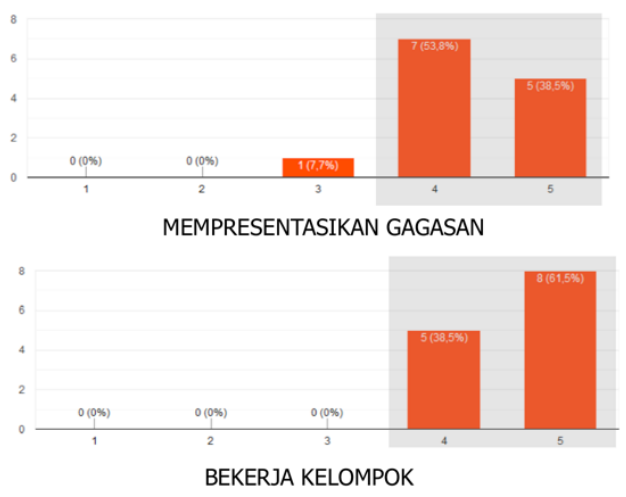

Gambar 6. Kemampuan yang didapatkan mahasiswa dalam proses pembelajaran Sumber: Data evaluasi dosen oleh mahasiswa, Program Magister Teknik Arsitektur UGM, 2020

\section{Menyesuaikan Bentuk Pembelajaran Rancang Kota: Identifikasi Kebutuhan Adaptasi Kebiasaan Baru}

Secara normatif, pada saat pemberlakuan proses pembelajaran jarak jauh, terjadi perubahan pada komponen surface structure (ruang kelas serta ruang studio dan fasilitasnya), sedangkan komponen ruang kota sebagai laboratorium kasus nyata menjadi 'hilang'. Ruang kelas dan ruang studio berubah menjadi ruang-ruang personal di lingkungan masing-masing, sehingga dalam pembelajaran studio rancang kota atmosfer kerja kreatif dan kompetitif dan juga proses interaksi sosial secara langsung tidak didapatkan. Sementara itu, karena pendalaman empirik tidak dapat dilakukan dalam pembelajaran jarak jauh, komponen epistemological principles juga memerlukan penyesuaian dalam pembelajaran, bagaimana kemampuan menemukenali karakter kawasan, potensi dan permasalahan dapat dicapai melalui konten yang tepat. Lebih lanjut, perubahan lingkungan fisik pembelajaran serta penyesuaian konten pada komponen epistemological principles menuntut adanya penyesuaian metode pada komponen pedagogical forms, perlu adanya penyesuaian metode interaksi dan komunikasi yang tepat antar pelaku pembelajaran empirik dan teoretik dalam mencapai target capaian pembelajaran. 


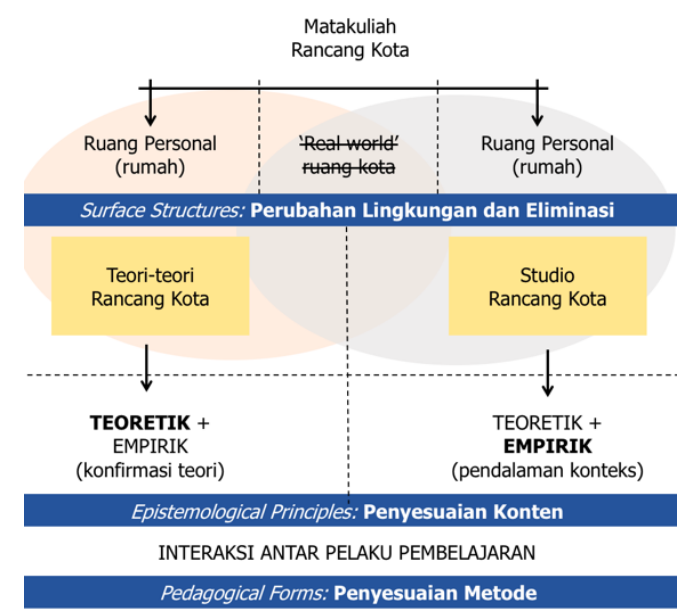

Gambar 7. Perubahan dalam pembelajaran jarak jauh pendidikan rancang kota Sumber: Hasil analisis, 2020

Dalam kaitannya dengan pemenuhan capaian pembelajaran pada pembelajaran jarak jauh matakuliah kasus studio rancang kota, untuk mengarah pada capaian pembelajaran pertama, mahasiswa masih dapat melakukan pendalaman teoretik dan pemahaman bagaimana teoretik tersebut berada dalam wujud empiriknya melalui preseden untuk mendapatkan kemampuan mengaplikasikan teori, prinsip, dan standar/kaidah rancang kota secara normatif dan inovatif. Namun demikian, jika kajian preseden dipandang belum cukup dalam memberikan pemahaman implementasi teori, perlu adanya penyesuaian konten di mana konfirmasi teori tetap dilakukan langsung di lapangan dengan pertimbangan keterbatasan luas area observasi yang dapat dilakukan secara individual serta keragaman lingkungan kasus individu yang relevan dengan teori terkait.

Pada target capaian pembelajaran yang ke dua, perlu penyesuaian metode interaksi dan komunikasi antar pelaku pembelajaran dalam upaya pendalaman konteks karakter dan permasalahan kawasan untuk mendapatkan pemahaman yang setara dengan pembelajaran tatap muka dan atmosfer interaksi sosial pada observasi lapangan ruang-ruang kota. Sementara itu dalam menuju target capaian pembelajaran yang ke tiga, perlu penyesuaian metode untuk menciptakan studio culture yang mampu menstimulasi kerja kreatif dan kompetitif. Dalam hal ini, perlu pertimbangan proporsi kerja studio secara individu dan kelompok yang proporsional, sehingga interaksi sosial tidak terhalang oleh lokasi individu yang berjauhan, selain itu juga perlu penyesuaian metode komunikasi antara mahasiswa dan mentor yang lebih kreatif dan interaktif.

\section{Mencari Bentuk Pembelajaran Rancang Kota: Pengembangan Konten dan Metode Alternatif}

Dalam langkah lanjut, perlu dicari bentuk baru dalam pembelajaran adaptasi kebiasaan baru untuk komponen pedagogi studio desain dalam bentuk ruang fisik dan ruang-ruang kota, sekaligus untuk memenuhi defisiensi pada komponen empirik rancang kota, serta pembaharuan pada komponen metode komunikasi/ interaksi antar pelaku pembelajaran. Dari hasil evaluasi pembelajaran di atas, juga didapatkan preferensi mahasiswa terhadap sistem pembelajaran matakuliah studio 
selanjutnya jika pandemi masih belum berakhir, yaitu 23\% mahasiswa tetap menginginkan studio dilaksanakan secara luring, $1 \%$ mahasiswa bisa menerima pelaksanaan studio secara daring, sedangkan sebagian besar mahasiswa (69\%) menginginkan studio dilakukan secara blended luring dan daring. Gambaran preferensi dari hasil evaluasi ini memberikan tantangan dalam pengembangan sistem baru pembelajaran rancang kota khususnya untuk matakuliah studio.

Objek eksplorasi dan inovasi dalam pembelajaran rancang kota untuk adaptasi kebiasaan baru adalah komponen-komponen pedagogi rancang kota melalui penyesuaian dan pembaharuan konten serta metode. Dalam epistemological principles, untuk komponen teoretik dalam pembelajaran teori rancang kota tidak banyak mengalami kendala dalam pembelajaran jarak jauh. Pembekalan materi bahkan memiliki kesempatan lebih banyak dalam melibatkan profesional rancang kota dan narasumber di luar kampus untuk memperkaya wawasan tanpa terikat ruang fisik melalui pembelajaran jarak jauh. Pengkayaan wawasan juga dapat diberikan melalui kajian-kajian kasus (preseden) sejalan dengan konten teori.

Di sisi lain, komponen empirik dalam pembelajaran teori rancang kota yang biasanya dapat dilakukan untuk tujuan konfirmasi teori melalui tugas kelompok, dilakukan penyesuaian konten pada skala kasus (dalam skala kawasan yang lebih kecil) dan teknis pelaksanaannya (dari tugas kelompok menjadi tugas individu di lokasi masing-masing). Penyesuaian konten ini akan memberikan pengetahuan dan pemahaman kasus 'real world' yang lebih beragam terhadap teori terhadap individu ataupun semua pelaku pembelajaran.

Komponen surface structure untuk ruang kerja studio desain sebagai wadah interaksi sosial dan stimulan kreativitas tidak mudah untuk digantikan. Demikian pula 'real world' ruang kota sebagai sarana pendalaman konteks lapangan. Satu hal yang dapat dioptimalkan adalah pembaharuan pada metode interaksi dan komunikasi antar mahasiswa serta antara mentor dan mahasiswa, bagaimana metode yang tepat untuk menciptakan komunikasi interaktif dan iklim kompetisi yang kondusif dalam menstimulasi gagasan-gagasan desain.

Presentasi dan kritik desain dalam setiap pertemuan pembelajaran studio dengan cara interaktif (drawing, conversing, model-making) tidak sekedar verbal ataupun tulisan melalui media digital baik oleh mentor ataupun peer review dapat membantu mengembalikan interaksi dan komunikasi dalam ruang studio. Perpaduan pendekatan sinkronus dan asinkronus dalam pembelajaran jarak jauh studio rancang kota dapat juga membantu menguatkan kontinuitas studio culture. Pemberian target tugas untuk setiap pertemuan pembelajaran akan memberikan waktu yang fleksibel tapi menuntut kontinuitas sesuai dengan kecepatan kerja dan kondisi masingmasing mahasiswa. Pendekatan asinkronus memungkinkan penggunaan waktu yang lebih fleksibel untuk berpikir lebih mendalam dalam proses desain.

Menurut Pafka dan Dovey (2018), metode mapping komponen-komponen kawasan tidak bisa dihilangkan dari rangkaian proses pemahaman karakter kawasan. Pada umumnya untuk menggantikan survai lapangan digunakan beberapa platform di antaranya google earth dan google streetview untuk pemahaman tiga dimensional ruang. Dalam pembelajaran luring platform ini digunakan untuk membuat peta 
dasar, mapping peta tematik dilakukan di lapangan, sedangkan dalam pembelajaran daring platform digunakan untuk membuat peta dasar sekaligus mapping peta tematik. Namun demikian, platform ini dipandang belum cukup dalam memberikan gambaran kawasan yang utuh, sense of place, ragam aktivitas dan interaksi manusia dalam konteks kawasan tidak dapat diidentifikasi dengan mudah hanya melalui gambar baik dua dimensi ataupun tiga dimensi. Oleh karena itu, pertimbangan penggunaan proses blended yang memasukkan unsur luring dalam pendalaman konteks ruang kota dapat menjadi alternatif, tentu saja dengan pembatasanpembatasan aktivitas dalam norma adaptasi kebiasaan baru.

Dalam matakuliah teori perlu penyesuaian metode yang tepat (selain penyesuaian konten), terutama dalam kuliah lapangan untuk memahami komponen empirik sebagai objek konfirmasi teori. Penggunaan video yang merupakan rekaman asinkronus dapat menjadi bahan kajian dan diskusi pengganti kuliah lapangan untuk konfirmasi teori, sedangkan video yang merupakan materi sinkronus lebih bersifat interaktif, di mana dosen berada di lapangan untuk merekam suasana secara langsung dan mahasiswa bisa langsung berinteraksi untuk mendapatkan pemahaman lapangan.

Metode ini juga bisa digunakan dalam membantu pemahaman dan pendalaman komponen empirik konteks 'real world' kasus studio, dengan fokus amatan yang lebih signifikan dan komprehensif, meskipun juga tidak sekuat pengalaman lapangan yang dirasakan ketika berada pada kawasan tersebut. Dalam proses pendalaman konteks tersebut, interaksi dengan komunitas, pakar dan akademisi terkait juga dapat memanfaatkan bantuan teknologi daring dalam satu bentuk forum diskusi dan presentasi.

\section{Kesimpulan}

Dalam mencari bentuk pembelajaran rancang kota pada konteks adaptasi kebiasaan baru ini sangat penting untuk memperhatikan target capaian pembelajaran pada matakuliah, bagaimana target tersebut dapat tercapai dalam kondisi pembelajaran jarak jauh. Komponen-komponen pedagogi, dalam hal ini, menjadi sasaran kajian sekaligus sebagai objek pembaharuan.

Pada pembelajaran studio rancang kota, komponen yang krusial untuk penyesuaian dan pembaharuan adalah pada studio culture, baik kerja studio secara fisik ataupun pemahaman lapangan. Hal yang dapat dilakukan sejauh ini adalah memperbaharui metode komunikasi dan interaksi antar pelaku pembelajaran seoptimal mungkin mendekati atmosfer kerja studio yang kondusif dan kompetitif. Penggunaan blended learning dengan memasukkan proses luring pada bagian awal pendalaman konteks melalui observasi lapangan secara langsung menjadi bagian yang dapat dipertimbangkan.

Secara mendasar, efektivitas bentuk baru dalam pembelajaran rancang kota selama diberlakukan pembelajaran jarak jauh memang belum teruji. Namun setidaknya di masa depan dapat menjadi metode pembelajaran alternatif dan menjadi referensi pengembangan metode pembelajaran rancang kota yang lebih baik, terutama dalam 
hal koneksi profesional, jangkauan nasional dan internasional, serta pemanfaatan teknologi baru.

\section{Ucapan Terima Kasih}

Ucapan terima kasih disampaikan pada Pengelola Program Studi Magister Teknik Arsitektur FT UGM untuk ijin dalam akses data hasil evaluasi pembelajaran dan juga kepada segenap mahasiswa konsentrasi Desain Kawasan Binaan Magister Arsitektur FT UGM Angkatan 2019 atas kerjasama selama proses pembelajaran studio dan kontribusinya pada proses evaluasi hasil pembelajaran.

\section{Daftar Pustaka}

Abrams, C. (1971). The language of cities: A glossary of terms. New York: Viking Adult. Banerjee, T. \& Loukaitou-Sideris, A. (Eds). (2011). Companion to urban design. New York: Routledge.

Keswani, K. (2019). Urban design studio pedagogy: Thinking about informality. New Design Ideas, vol. 3 no. 2, 113-123.

Lukovich, T. (2017). On pedagogy for urban design - some observations. YBL Journal of Built Environment, Vol. 5, Issue 1, 84-101.

Lynch, K. (1981). A theory of good city form. Cambridge: MIT Press.

Pafka, E., Dovey, K. (2018). Urban design pedagogy: Mapping urbanities. New York: Routledge.

Rossi, A. (1984). The architecture of the city. Cambridge: MIT Press.

Tim Penyusun Proposal MRK UGM. (2019). Naskah akademik usulan pendirian Program Studi Rancang Kota Departemen Teknik Arsitektur dan Perencanaan UGM. Tidak dipublikasikan.

Yorgancioğlu, D. (2020). Critical reflections on the surface, pedagogical and epistemological features of the design studio under the "new normal" conditions. Journal of Design Studio, vol. 2 no. 1, 25-36. 